\title{
Analytical Method Development And Validation Of Rp-Hplc Method For Simultaneous Estimation Of PyridoxamineDihydrochloride And Acetylcysteine In \\ Tablet Dosage Form.
}

\author{
SNEHA S. GHULE ${ }^{1 *}$, ASHPAK M. TAMBOLI ${ }^{1}$, SNEHAL D. PATIL $^{1}$ \\ ${ }^{1}$ Department of pharmaceutical Chemistry ,Sahyadri College of Pharmacy, Methwade, Sangola, \\ 413307, Solapur, Maharashtra, India \\ Email Id : snehaghule02@gmail.com
}

\begin{abstract}
:
A reverse phase high performance liquid chromatography (RP-HPLC) method for the simultaneous estimation of Pyridoxamine dihydrochloride and Acetylcysteine in marketed formulation is developed. Chromatography carried out at $30^{\circ} \mathrm{C}$ temperature on Agilent Zorbax Bonus-RP (250 x $\left.4.6 \mathrm{~mm}, 5 \mu\right)$ coloum. Coloum using a mobile phase $0.1 \%$ trifluroacetic acid in water: acetonitrile $(80: 20 \mathrm{v} / \mathrm{v})$ with flow rate $1 \mathrm{ml} / \mathrm{min}$ (DAD scan at 210nm). Validation parameter such as system suitability, linearity, precision, accuracy are considered as reported International Conference on Harmonization guidelines. The retention times for Pyridoxamine dihydrochloride and Acetylcysteine are $2 \mathrm{~min}$ and $3.4 \mathrm{~min}$. The linearity range for Pyridoxamine dihydrochloride and Acetylcysteine is $30-70 \mu \mathrm{g} / \mathrm{ml}$ and $180-420 \mu \mathrm{g} / \mathrm{ml}$. The \%RSD for accuracy were found to be less than $2 \%$. Hence the proposed method was found to be accurate, precise, reproducible and specific and can be used for simultaneous analysis of these drugs in tablet formulation.
\end{abstract}

KEY WORDS :Pyridoxaminedihydrochloride, Acetylcysteine, RP-HPLC

\section{INTRODUCTION :}

Pyridoxaminedihydrochloride chemical name is 4-(aminomethyl)-5-(hydroxymethyl)-2-methylpyridin-3-ol dihydrochloride.It is small molecule derivative of pyaridoxal phosphate (vitamin $\mathrm{B}_{6}$ ) with the distinct chemical structure that inhibit the formation of advanced glycation end-products (AGE).Pyridoxaminedihydrochloride is used for the treatment of vitamin deficiency. It also used in the Diabetic neuropathy. It is block the pathogenic oxidative pathways in progression of diabetic neuropathy. Pyridoxamine inhibits a broad range of pathogenic oxidative chemistries that lead to AGE formation, including activity against toxic carbonyls, reactive oxygen species, and the conversion of glycosylated proteins to AGEs. 


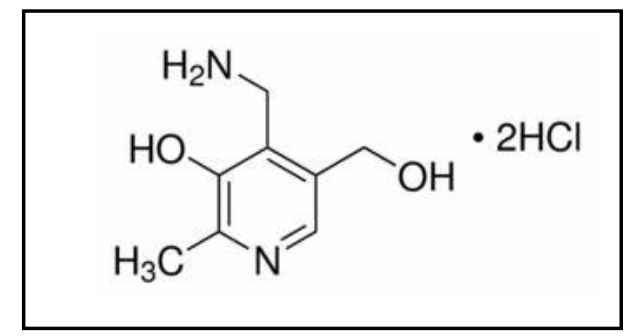

\section{Figure 1: Structure of Pyridoxamine dihydrochloride}

Acetylcysteine is also known as (N-Acetylcysteine or N-acetyl-L-cysteine or NAC) is primarily used as a mucolytic agent. It is used as an antidote for acetaminophen overdose to prevent hepatic injury.Acetylcysteine can be also used as a general antioxidant which can help mitigate symptoms for a variety of diseases exacerbated by reactive oxygen species. Acetylcysteine is in a class of medications called mucolytic agents. Intravenous and oral formulations of Acetylcysteine are available for the treatment of paracetamol overdose.

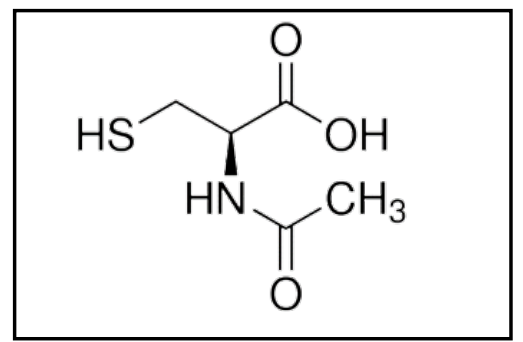

\section{Figure 2: Structure of Acetylcysteine}

Literature review reveals only individual methods for estimation of Pyridoxamine dihydrochlorideand Acetylcysteine but methods were reported for simultaneous estimation of Pyridoxamine dihydrochloride and Acetylcysteine. So method was developed method more superior than previously published method of individual estimation of both drugs. The composition of mobile phase is adjusted to maintain highly accurate and specific results. The detection wavelength of $210 \mathrm{~nm}$ was chosen in order to achieve a good sensitivity for quantitative determination of Pyridoxamine dihydrochloride and Acetylcysteine in solid dosage form.

\section{MATERIAL AND METHODS:}

\section{Chemical and reagents:}

Analytical pure sample of Pyridoxamine dihydrochloride and Acetylcysteine were received as a gift sample from Cipla Private Limited were used in the study. The pharmaceutical dosage form used in this study was NEFROSAVE FORTE labeled to contain Acetylcysteine and Pyridoxamine dihydrochloride 300/50 mg per tablet. The solvent used were of HPLC 0.1\% TFA water and Acetonitrile used in preparation of mobile phase.

\section{Preparation of mobile phase:}

$1000 \mathrm{ml}$ mobile phase was prepared by mixing $800 \mathrm{ml} 0.1 \%$ trifluroacetic acid in water and 200ml Acetonitrile.

\section{Apparatus and chromatographic conditions:}

Chromatographic separation Agilent zorbax bonus-RP $(250 \times 4.6 \mathrm{~mm}, 5 \mu)$ coloum was used for separation. The elution was carried out gradient at flow rate of $1 \mathrm{ml} / \mathrm{min}$ using $0.1 \%$ trifluroaceticacid : acetonitrile $(80: 20 \mathrm{v} / \mathrm{v})$ mobile phase. 


\section{Preparation of Standardstock solution :}

Standard stock solution of Acetylcysteine :

Initially prepare a standard stock solution (SSS-1) of by adding 30mg of Acetylcysteine in 10ml volumetric flask $\&$ add $5 \mathrm{ml}$ diluent, mix for 2 minutes and make the volume to $10 \mathrm{ml}$ with diluent ( conc.ofAcetylcysteine $=3000$ $\mu \mathrm{g} / \mathrm{ml})$.

\section{Standard stock solution of Pyridoxamine dihydrochloride :}

Then prepare a standard stock solution (SSS-2) of pyrodoxaminedihydrochloride by adding $5 \mathrm{mg}$ in $10 \mathrm{ml}$ volumetric flask \& add $5 \mathrm{ml}$ diluent, mix for $2 \mathrm{~min}$. \& make the volume to $10 \mathrm{ml}$ with diluent.(conc. Of Pyridoxamine dihydrochloride $=500 \mu \mathrm{g} / \mathrm{ml}$ ).

Then add $1.0 \mathrm{ml}$ of SSS-1 \& $1.0 \mathrm{ml} \mathrm{SSS-2}$ in $10 \mathrm{ml}$ volumetric flask and add $5 \mathrm{ml}$ diluent and vortex and make up the volume with diluent. ( conc.ofAcetylcysteine $=3000 \mu \mathrm{g} / \mathrm{ml} \&$ conc. Of Pyridoxaminedihydrochloride $=$ $500 \mu \mathrm{g} / \mathrm{ml})$.

\section{Selection of wavelength:}

The sample was scanned from 200-400 nm with PDA detector. The wavelength selected for analysis chosen was $210 \mathrm{~nm}$ on basis of appropriate intensity of Acetylcysteine and Pyridoxaminedihydrochloride.

Table.1 Chromatographic conditions:

\begin{tabular}{|c|c|}
\hline Coloum temperature & $30^{\circ} \mathrm{c}$ \\
\hline Flow rate & $1 \mathrm{ml} / \mathrm{min}$ \\
\hline Mobile phase & $0.1 \%$ TFA Water : Acetonitrile \\
\hline Runtime & 8 Minutes \\
\hline Injection volume & $10 \mu \mathrm{l}$ \\
\hline Wavelength & $210 \mathrm{~nm}$ \\
\hline Diluent & Mobile phase \\
\hline Column & Agilent zobrax bonus- RP \\
\hline Mobile phase ratio & $80: 20 \% \mathrm{v} / \mathrm{v}$ \\
\hline Rt of Pyridoxaminedihydrochloride\& Acetylcysteine & 2 min \& 3.4 min \\
\hline
\end{tabular}

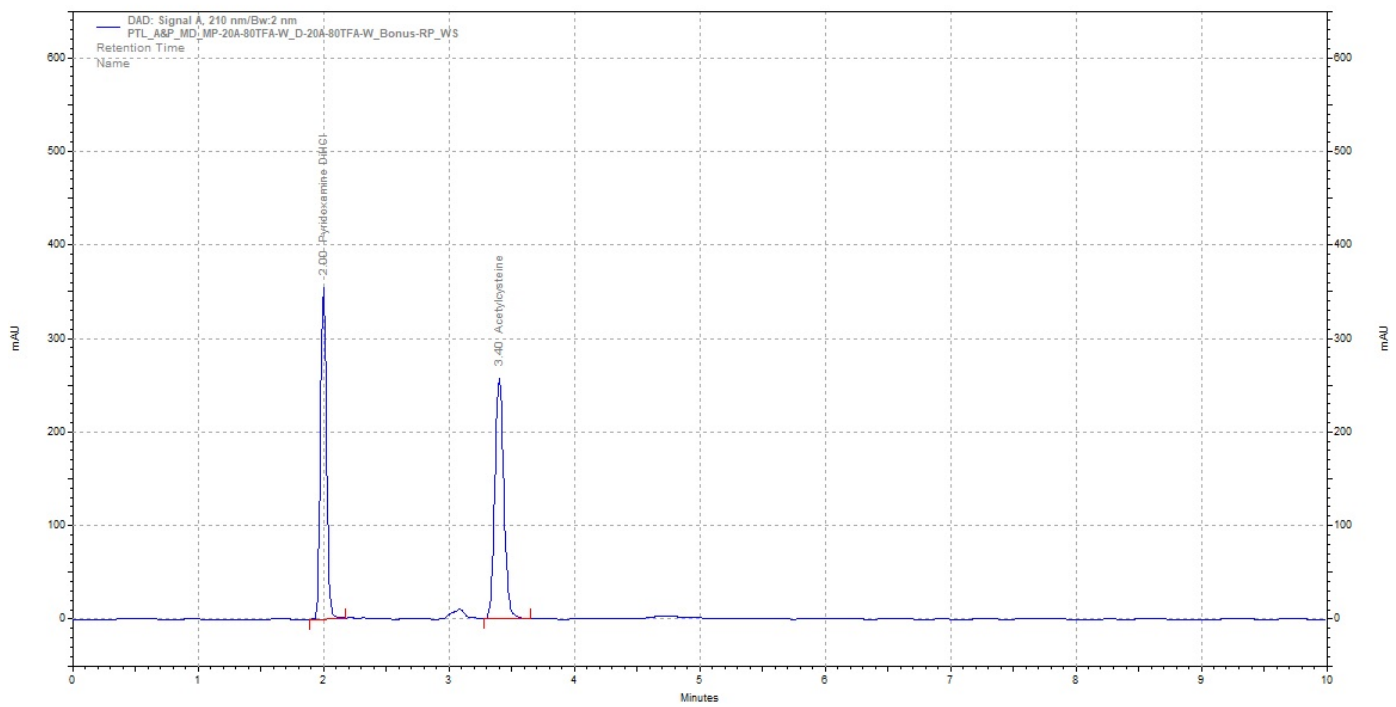

Figure. 3: Chromatogram of standard mixture of Pyridoxaminedihydrochloride\&Acetylcysteine 


\section{Preparation of sample solution :}

\section{Tablet sample solution (TSS) :}

10 tablets were weighed and average weight was calculated and tablets were crushed in mortar and pestle.Powder weight equivalent to $3000 \mu \mathrm{g}$ Acetylcysteine and $500 \mu \mathrm{g}$ Pyridoxamine dihydrochloride were weighed into $10 \mathrm{ml}$ volumetric flask \& add $5 \mathrm{ml}$ diluent, sonicate for 10 minutes and make the volume to $10 \mathrm{ml}$ with diluent. ( conc.ofAcetylcysteine $=3000 \mu \mathrm{g} / \mathrm{ml}$, Pyridoxaminedihydrochloride $=500 \mu \mathrm{g} / \mathrm{ml}$ ).

\section{Assay :}

Individual samples of Acetylcysteine and Pyridoxamine dihydrochloride were prepared of $300 \mu \mathrm{g} / \mathrm{ml}$ and 50 $\mu \mathrm{g} / \mathrm{ml}$, respectively and peaks were for identified from Retention Time. Blank was injected to ensure there is no blank peak interfering with the main analyte peaks.

\section{METHOD VALIDATION :}

\section{Linearity :}

A series of standard solution 30-70 $\mu \mathrm{g} / \mathrm{ml}$ of Pyridoxamine dihydrochloride and 180-420 $\mu \mathrm{g} / \mathrm{ml} \mathrm{of}$ Acetylcysteine were prepared. An aliquot of $10 \mu \mathrm{l}$ of each solution was injected 5 times for each standard solutions and peak area was observed. 5 samples of varying concentrations ranging from $60-140 \%$ were made. The results obtained are shown in table (Table 4) for Pyridoxamine dihydrochlorideand in (Table 5) for Acetylcysteine.

Table 2: Linearity dilutions :

\begin{tabular}{|c|c|c|c|c|c|}
\hline Sr.No & $\begin{array}{c}\text { Pyridoxamine } \\
\text { dihydrochloride } \\
(\boldsymbol{\mu g} / \mathbf{m l})\end{array}$ & $\begin{array}{c}\text { Acetylcysteine } \\
\mathbf{( \mu g / m l )}\end{array}$ & $\begin{array}{c}\text { Volume of } \\
\text { Pyridoxamine } \\
\text { dihydrochloride } \\
\text { stock solution } \\
\text { to be taken(m) }\end{array}$ & $\begin{array}{c}\text { Volume of } \\
\text { Acetylcysteine } \\
\text { stock solution } \\
\text { to be taken } \\
\mathbf{( m l )}\end{array}$ & $\begin{array}{c}\text { Diluted to } \\
\text { volume (ml) }\end{array}$ \\
\hline 1 & 30 & 180 & 0.6 & 0.6 & 10 \\
\hline 2 & 40 & 240 & 0.8 & 0.8 & 10 \\
\hline 3 & 50 & 300 & 1 & 1 & 10 \\
\hline 4 & 60 & 360 & 1.2 & 1.2 & 10 \\
\hline 5 & 70 & 420 & 1.4 & 1.4 & 10 \\
\hline
\end{tabular}

\section{Precision :}

The precision of the method was done by system precision and method precision. The percentage RSD value was found to be within the limit below 2. The percentage RSD values less than 2 for peak area ratioof Pyridoxamine dihydrochlorideand Acetylcysteine obtained, thus the results showing that equipment used for the work. 
Accuracy :

The accuracy of the method was determined by calculating recovery values of Pyridoxamine dihydrochloride and Acetylcysteine by standard addition method. The recovery studies were carried out at different levels of 80$120 \%$ and average \% recovery was observed. Samples were prepared of $80 \%, 100 \%$ and $120 \%$ concentration by spiking the same amount of concentration given below in table for both Acetylcysteine (table 9) and Pyridoxamine dihydrochloride (table 8). Samples were injected in duplicate to calculate \% RSD. \% recovery was also calculated.

\section{System suitability :}

A single sample was prepared as described and 5 injections were made from same sample and checked for system suitability.

\section{Limit of detection (LOD) and Limit of Quantification (LOQ) :}

The LOD and LOQ were found to be $0.56 \mu \mathrm{g} / \mathrm{ml}$ and $1.70 \mu \mathrm{g} / \mathrm{ml}$ for Pyridoxamine dihydrochloride the LOD and LOQ were found to be $14.08 \mu \mathrm{g} / \mathrm{ml}$ and $42.65 \mu \mathrm{g} / \mathrm{ml}$ for Acetylcysteine,respectively.

\section{RESULT AND DISCUSSION :}

Table 3: Assay data of Pyridoxamine dihydrochloride and Acetylcysteine

The \% assay was found to be $99.61 \%$ for Pyridoxamine dihydrochloride and $100.25 \%$ for Acetylcysteine. Assay result shown in below table 3 .

\begin{tabular}{|c|c|c|c|c|}
\hline \multicolumn{3}{|c|}{ Pyridoxamine dihydrochloride } & \multicolumn{2}{c|}{ Acetylcysteine } \\
\hline Sample & Working Standard & Drug Product & Working Standard & Drug Product \\
\hline Area & 2735672.2 & 2725104 & 2801012.2 & 2808113 \\
\hline Assay & -- & 99.61 & -- & 100.25 \\
\hline
\end{tabular}

\section{Table 4:Linearity data of Pyridoxamine dihydrochloride}

Linearity was studied by plotting a graph of area v/s concentration. A series of standard solution of Pyridoxamine dihydrochloride were prepared in the concentration range of about $30 \mu \mathrm{g} / \mathrm{ml}$ to $70 \mu \mathrm{g} / \mathrm{ml}$ is shown in belowtable.Linearitygraph of Pyridoxaminedihydrochloride shown in Figure.no.4.

\begin{tabular}{|c|c|c|}
\hline Linearity level \% & Concentration $\mathbf{( \mu g} / \mathbf{m l})$ & Peak area \\
\hline 60 & 30 & 1660163 \\
\hline 80 & 40 & 2205780 \\
\hline 100 & 50 & 2734970 \\
\hline 120 & 60 & 3262741 \\
\hline 140 & 70 & 3798616 \\
\hline
\end{tabular}




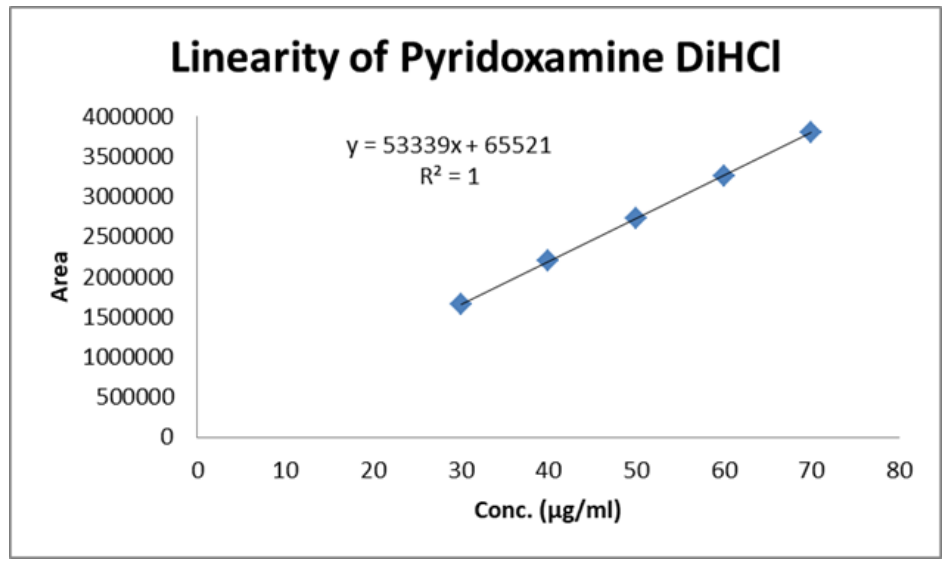

Figure.4:Linearity graph of Pyridoxaminedihydrochloride

Table 5:Linearity data of Acetylcysteine

Linearity was studied by plotting a graph of area v/s concentration. A series of standard solution of Acetrylcysteine were prepared in the concentration range of about $180 \mu \mathrm{g} / \mathrm{ml}$ to $420 \mu \mathrm{g} / \mathrm{ml}$ is shown in below table.Linearity graph of Acetylcysteine shown in Figure.no.5

\begin{tabular}{|c|c|c|}
\hline Linearity level \% & Concentration $\mathbf{( \mu g / m l )}$ & Peak area \\
\hline 60 & 180 & 1704234 \\
\hline 80 & 240 & 2262575 \\
\hline 100 & 300 & 2775515 \\
\hline 120 & 360 & 3353136 \\
\hline 140 & 420 & 3939717 \\
\hline
\end{tabular}

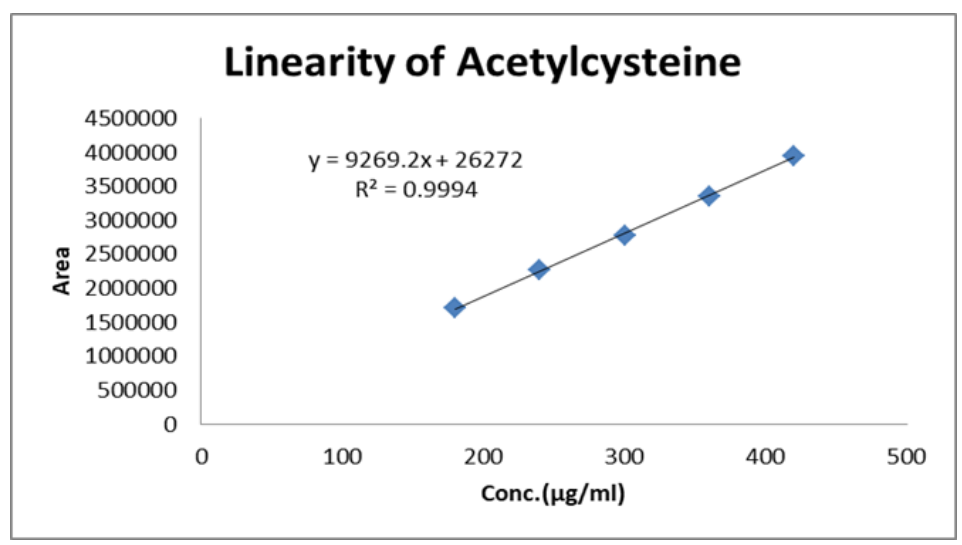

Figure.5:Linearity graph of Acetylcysteine

\section{Table 6: Precision data of Pyridoxamine dihydrochloride}

The precision of the Pyridoxamine dihydrochloridemethod was found tobe good with \% RSD less than 2, indicate that method was precise and the results presented below table. In this concentration of sample is $50 \mu \mathrm{g} / \mathrm{ml}$. 


\begin{tabular}{|c|c|c|}
\hline \multicolumn{3}{|c|}{ Pyridoxaminedihydrochloride } \\
\hline Conc of sample & Sample ID & Area \\
\hline 50 & Rep 1 & 2734970 \\
\hline 50 & Rep 2 & 2728190 \\
\hline 50 & Rep 3 & 2732303 \\
\hline 50 & Rep 4 & 2751647 \\
\hline 50 & Rep 5 & 2731251 \\
\hline \multicolumn{2}{|c|}{ Average } & 2735672.2 \\
\hline STDEV & 9254.311898 \\
\hline RSD & 0.34 \\
\hline
\end{tabular}

\section{Table 7: Precision data of Acetylcysteine}

The precision of theAcetylcysteinemethod was found to be good with \% RSD less than 2, indicate that method was precise and the results presented below table. In this concentration of sample is $300 \mu \mathrm{g} / \mathrm{ml}$.

\begin{tabular}{|c|c|c|}
\hline \multicolumn{3}{|c|}{ Acetylcystiene } \\
\hline Conc. of sample & Sample ID & Area \\
\hline 300 & Rep 1 & 2775515 \\
\hline 300 & Rep 2 & 2831962 \\
\hline 300 & Rep 3 & 2785807 \\
\hline 300 & Rep 4 & 2804169 \\
\hline 300 & Rep 5 & 2807608 \\
\hline & & 21752.39 \\
\hline & Average & 0.78 \\
\hline
\end{tabular}

Table 8: Accuracy data for Pyridoxaminedihydrochloride by RP-HPLC:

In accuracy study percentage recovery range of Pyridoxamine dihydrochloride is $100.97 \%$ to $100.28 \%$. The range of $\% \mathrm{RSD}$ is $0.41 \%$ to $0.36 \%$.

\begin{tabular}{|c|c|c|c|c|c|c|c|c|}
\hline $\begin{array}{l}\text { Sample } \\
\text { ID }\end{array}$ & Reps & $\begin{array}{l}\text { Spiked } \\
\text { Conc. } \\
\text { (ug/ml) }\end{array}$ & Area & $\begin{array}{l}\text { Amt } \\
\text { Recovered } \\
\text { (ug/ml) }\end{array}$ & $\begin{array}{l}\% \\
\text { Recovery }\end{array}$ & Average & STDEV & RSD \\
\hline \multirow{2}{*}{$80 \%$} & Rep 1 & 39.988 & 2262575 & 40.38 & 100.97 & \multirow{2}{*}{100.68} & \multirow{2}{*}{0.4172} & \multirow{2}{*}{0.41} \\
\hline & Rep 2 & 39.988 & 2249354 & 40.14 & 100.38 & & & \\
\hline \multirow{2}{*}{$100 \%$} & Rep 1 & 49.985 & 2775515 & 49.53 & 99.09 & \multirow{2}{*}{100.10} & \multirow{2}{*}{1.424987} & \multirow{2}{*}{1.42} \\
\hline & Rep 2 & 49.985 & 2831962 & 50.54 & 101.10 & & & \\
\hline \multirow{2}{*}{$120 \%$} & Rep 1 & 59.982 & 3353136 & 59.84 & 99.76 & \multirow{2}{*}{100.02} & \multirow{2}{*}{0.36466} & \multirow{2}{*}{0.36} \\
\hline & Rep 2 & 59.982 & 3370470 & 60.15 & 100.28 & & & \\
\hline
\end{tabular}

Table 9: Accuracy data for Acetylcysteine by RP-HPLC: 
In accuracy study percentage recovery range of Acetylcysteine is $100.79 \%$ to $99.57 \%$. The range of \% RSD is $0.35 \%$ to $0.13 \%$.

\begin{tabular}{|c|c|c|c|c|c|c|c|c|}
\hline $\begin{array}{c}\text { Sample } \\
\text { ID }\end{array}$ & Reps & $\begin{array}{c}\text { Spiked } \\
\text { Conc. } \\
\text { (ug/ml) }\end{array}$ & Area & $\begin{array}{c}\text { Amt } \\
\text { Recovere } \\
\text { d (ug/ml) }\end{array}$ & $\begin{array}{c}\% \\
\text { Recovery }\end{array}$ & Average & STDEV & RSD \\
\hline \multirow{2}{*}{$80 \%$} & Rep 1 & 239.928 & 2205780 & 241.82 & 100.79 & \multirow{2}{*}{101.04} & \multirow{2}{*}{0.35211} & \multirow{2}{*}{0.35} \\
\hline & Rep 2 & 239.928 & 2216678 & 243.01 & 101.29 & & & \\
\hline \multirow{2}{*}{$100 \%$} & Rep 1 & 299.91 & 2734970 & 299.83 & 99.97 & \multirow{2}{*}{99.85} & \multirow{2}{*}{0.17524} & \multirow{2}{*}{0.18} \\
\hline & Rep 2 & 299.91 & 2728190 & 299.09 & 99.73 & & & \\
\hline \multirow{2}{*}{$120 \%$} & Rep 1 & 359.892 & 3262741 & 357.69 & 99.39 & \multirow{2}{*}{99.48} & \multirow{2}{*}{0.12951} & \multirow{2}{*}{0.13} \\
\hline & Rep 2 & 359.892 & 3268754 & 358.35 & 99.57 & & & \\
\hline
\end{tabular}

Table 10: system suitability parameter

Parameter of system suitability is Retention time, Theroticalplates,Asymmetry(Tailing factor), Resolutionis shown in table 10.

\begin{tabular}{|c|c|c|}
\hline Parameter & Pyridoxamine dihydrochloride & Acetylcysteine \\
\hline Retention time & 2 & 3.4 \\
\hline Therotical plates & 7971 & 10424 \\
\hline Asymmetry (Tailing factor) & 1.03 & 1.06 \\
\hline Resolution & 0.00 & 12.42 \\
\hline
\end{tabular}

\section{Table 11:LOD\& LOQ Data}

LOD and LOQ of Pyridoxamine dihydrochloride is $0.56 \mu \mathrm{g} / \mathrm{ml}$ and $1.70 \mu \mathrm{g} / \mathrm{ml}$ and Acetylcysteine is $14.08 \mu \mathrm{g} / \mathrm{ml}$ and $42.65 \mu \mathrm{g} / \mathrm{ml}$.

\begin{tabular}{|c|c|c|}
\hline Drugs & LOD $\boldsymbol{\mu g} / \mathbf{m l}$ & LOQ $\mathbf{\mu g} / \mathbf{m l}$ \\
\hline $\begin{array}{c}\text { Pyridoxamine } \\
\text { dihydrochloride }\end{array}$ & 0.56 & 1.70 \\
\hline Acetylcysteine & 14.08 & 42.65 \\
\hline
\end{tabular}

\section{CONCLUSION :}

It concludes that the developed method is simple, accurate and precise and suitable for the routine analysis. The developed methods were validated as per ICH guidelines and were found to be within limit.

\section{ACKNOWLEDGEMENT :}

I am very much thankful to sahyadri college of pharmacy, Methwade (Sangola), Maharashtra, for giving permission to carry out my work. 


\section{REFERENCES :}

[1] United States Pharmacopeial convention: United States Pharmacopoeia 36; National Formulary 31, US Pharmacopoea Convention, Rockville, MD, 2013.

[2] KD TripathiEssential of Medical Pharmacology, 6th edition, Jaypee Brothers Medical Publishers, 2008.

[3] BharathiD.,Development and validation of RP-HPLC method for simultaneous estimation of pyrodoxaminedihydrochloride and actylcysteine in tablet dosage form,International journal of medicinal chemistry and analysis.Vol.6, 94-99, 2016.

[4] British Pharmacopoeia vol-I Introduction General notice Monograph, Medicinal and Pharmaceutical substances (A1),45,2004.

[5] Nalluri N. J, Development and validation of a new RP-HPLC method for simultaneous estimation of $\mathrm{N}$-Acetylcysteine and L-arginine in combined dosage form,Original journal of chemistry,2014, 3:1372-1378.

[6] SudheerM., Analytical method development and validation of RP-HPLC method for simultaneous estimation of $\mathrm{N}$-Acetylcysteine and cefexime from its fixed dose combination. Research journal of pharmacy and technology. Vol. 9, 835-842, 2016.

[7] Vedang K. , A novel stability indicating RP-HPLC method for the simultaneous estimation of NAcetylcysteine and ambroxolin combined tablet dosage form. International journal of pharmaceutical sciences and research, vol. 8,2161-2167.

[8] K. SrinivasaRao, RP-HPLC Method for the Determination of Losartan Potassium and Ramipril in Combined Dosage Form. Indian Journal of Pharmaceutical Sciences, 108-111,2010

[9] Patel H. , RP-HPLC Method Development and Validation for Simultaneous Estimation of Cilnidipine and BisoprololFumarate in Tablet Dosage Form. International Journal of ChemTech Research. Vol. 12, 269-276, 2019.

[10] Patil S. , Development and validation of RP-HPLC method for the simultaneous estimation bisoprololfumarate and telmisartan from pharmaceutical formulations. International journal of pharmacy and analytical research. Vol. 9, 129-136,2020.

[11] More S. ,Development and Validation of RP-HPLC Method for the Simultaneous Estimation of Pregabalin and Amitriptyline Hydrochloride From Pharmaceutical Formulations. International Journal of Research and Analytical Reviews (IJRAR). Vol. 6, 667-678, 2019.

[12] Sohan S C. , RP-HPLC method for simultaneous estimation of amlodipine and metoprolol in tablet formulation. Asian Journal of Pharmaceutics.232-234, 2008.

[13] N. Mukuntha Kumar, Development and Validation of RP-HPLC Method for the Simultaneous Estimation of Telmisartan and Hydrochlorothiazide in Bulk and Pharmaceutical Dosage Form. International Journal of Pharma Sciences and Research (IJPSR).Vol. 5,646-654, 2014.

[14] M. PrasadaRao, Simultaneous estimation of Ramipril and OlmesartanMedoximil by RP-HPLC method. International Journal of Pharmaceutical Chemistry and Analysis, vol. 4, 106-111.

[15] NuranErcal, High-performance liquid chromatography assay for N-acetylcysteine in biological samples following derivatization with $\mathrm{N}$-( 1-pyrenyl)maleimide. Journal Of Chromatography B:Biomedical Applications, 229-234, 1996.

[16] ICH guidelines, validation of analytical procedures: text and methodology,Q2A(R1) Nov;2005.

[17] Snyder L. R.. Practical HPLC Method Development, John Wiley \& Sons Inc., Edition 2. 